\title{
RACTOPAMINA EM CARNE BOVINA, ESTADO DE RONDÔNIA, BRASIL.
}

RACTOPAMINE IN BEEF CATTLE FROM RONDÔNIA STATE, BRAZIL

\author{
G. M. C. ALVES ${ }^{1,2} ;$ M. A. A. BELO ${ }^{2,3 *}$
}

\section{RESUMO}

A ractopamina é um agonista beta-adrenérgico utilizado como aditivo na alimentação de animais de produção que visa modificar o metabolismo, favorecendo processos neoglicogênicos de quebra de tecido adiposo para produção de massa muscular, melhorando o rendimento de carcaça. Manter a qualidade dos produtos de origem animal e assegurar a harmonização dos procedimentos sanitários e fitossanitários constituem pré-requisitos básicos para a manutenção das exportações brasileiras. Exigências sanitárias da União Aduaneira, representada pela Federação Russa e Repúblicas do Kazaquistão e Bielorrússia, determinam a análise e certificação para este adrenérgico. Buscando atender as exigências destes mercados, este estudo objetivou avaliar a presença de resíduos de ractopamina na carne bovina em um matadouro-frigorífico habilitado para a União Aduaneira no Estado de Rondônia, Região Norte do Brasil. Durante os meses de dezembro de 2013 a agosto de 2015, foram realizadas 16.693 análises laboratoriais para a pesquisa de ractopamina em amostras de $200 \mathrm{~g}$ de músculo do dianteiro, coletadas aleatoriamente de uma carcaça por cada lote de animais abatidos destinados à União Aduaneira. Devidamente acondicionadas, as amostras foram congeladas a - 18- C por 24 horas, para serem enviadas para Laboratório Credenciado ao MAPA e acreditado na ISO 17025, localizado no Estado de São Paulo. A detecção da Ractopamina foi feita através do método de Cromatografia Líquida de Alta EficiênciaHPLC, atendendo à exigência para detecção e sensibilidade de $0,1 \mathrm{ng} / \mathrm{mL}$ (ppb), conforme protocolo metodológico POP-QV009, HPLC MS/MS.(EUROFINS). Os resultados demonstraram ausência de ractopamina em $100 \%$ das análises de carne bovina, garantindo a segurança alimentar para resíduos deste beta adrenérgico e atendendo às exigências da União Aduaneira.

PALAVRA-CHAVE: AGONISTAS BETA-ADRENÉRGICO, SEGURANÇA ALIMENTAR, RESÍDUOS

ÁREA TEMÁTICA: Higiene e Inspeção de Produtos de Origem Animal

\footnotetext{
${ }^{1}$ Médica Veterinária, Consultora e Auditora, Especialista em Inspeção e Tecnologia de Produtos de Origem Animal e Especialista em Segurança dos Alimentos, Ji-Paraná, RO.

${ }^{2}$ Laboratório de Farmacologia e Toxicologia Animal, Universidade Camilo Castelo Branco, Descalvado/SP.

${ }^{3}$ Departamento de Medicina Veterinária Preventiva e Reprodução Animal, FCAV-UNESP, Jaboticabal/SP.

*maabelo@hotmail.com.
} 